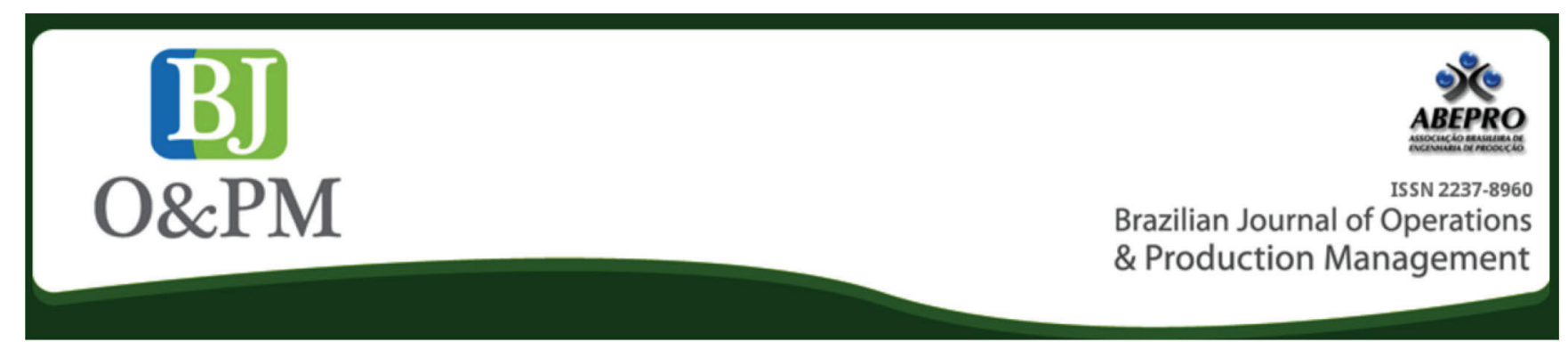

\title{
CRITICAL SUCCESS FACTORS ON PROJECT AND PROCESS MANAGEMENT IN COMPETITIVE STRATEGY IMPLEMENTATION
}

\author{
Suzy Almeida Ferreira \\ suzyalfer@gmail.com \\ Fluminense Federal University - \\ UFF, Niterói, Rio de Janeiro, Brazil. \\ Julio Vieira Neto \\ julion@id.uff.br \\ Fluminense Federal University - \\ UFF, Niterói, Rio de Janeiro, Brazil. \\ Haydee Maria Correia da \\ Silveira Batista \\ haydeemcsb@gmail.com \\ Fluminense Federal University - \\ UFF, Niterói, Rio de Janeiro, Brazil.
}

\begin{abstract}
Goal: Raise in the literature of project and process management the critical success factors needed to implement a competitive strategy aiming to rank them and to recommend guidelines for a successful competitive strategy implementation.

Design / Methodology / Approach: In order to reach the desired objectives, a research was carried out in the literature, enabling the creation of the questionnaire that was applied as a data collection instrument and the use of relative frequency analysis and measurement of the central tendency, mode, as the statistical treatments.

Results: All the 42 requirements raised in the literature were considered as critical success factors for competitive strategy implementation and the analysis of the professionals' answers made it possible to include a further 12 critical success factors.

Limitations of the investigation: The size of the sample, which was conditioned to the number of respondents of the questionnaire distributed by electronic means. And because the size of the population is unknown, it is not possible to realize generalizations.

Practical implications: A recommendation for companies was prepared through four priority actions in the competitive strategy implementation. The research concluded that, beyond the pillar's strategy, processes, and projects, the people, whether clients or employees, need to be included as one of the bases for competitive advantage.

Originality / Value: The scheme ranking the requirements' relevance for competitive strategy implementation is a way to support companies to promote actions to adapt the corporate environment, so that all of productive links are aligned with the strategic objectives.
\end{abstract}


Brazilian Journal of Operations \& Production Management

Volume 16, Número 4, 2019, pp. 605-616

DOI: 10.14488/BJOPM.2019.v16.n4.a6

\section{INTRODUCTION}

Competitiveness is increasingly present in companies, thus generating the need to assertively decide which strategy should be used in order to stay ahead of competitors. This fact requires that strategic management, through leadership, make decisions guided by the factors that influence business, coherently balancing competitiveness, growth and interest of those involved with the organization (Zollo et al., 2017). However, with unstable market dynamics through the evolution of technologies, regulatory changes, fluctuations in the economy, and varying customer expectations, companies face difficulties in achieving business strategies (Sull, 2007). For Cândido and Santos (2015), failure rate in strategy implementation is difficult to determine with assertiveness due to the different calculation methods; however, it is expressive in the studies.

Regardless of the percentage of failure, the fact is that implementing a competitive strategy is a challenge for organizations. Scenarios such as market changes, effective responses of the competition to strategy, insufficient resources, communication inefficiency, poor understanding and engagement of stakeholders, lack of focus, poorly designed business models and late application of timely and different contributions corroborate this difficulty in implementing the strategy (Sterling, 2003). And in the Brazilian scenario, Anholon et al. (2017) highlight the low active participation of the leadership in the process of ensuring that the strategy unfolds into actions.

To minimize this problem, companies must rely on ways to exploit their internal capacities in line with their strategies, and are able to respond to externals demands by integrating their operation with strategic aspects (Treinta et al., 2014). Based on that, process management can take a systemic approach that promotes the delivery of value to the market with continuously improved processes (Nara et al., 2014), and project management helps companies achieve their goals by delivering to organizations products or services that are transferred to the ongoing processes of the companies' operation (Freitas, 2016). Both methods orchestrated in parallel maximize the opportunity to reach the strategic objectives, one by contributing to the management of the execution of actions outlined in the strategic plan and the other by aligning the company's routine with the guidelines defined as organizational strategy.

In this context, the guiding question of the research is: How can companies maximize the assertiveness of competitive strategy implementation having project and process management as facilitators? The overall objective of the article is to identify the critical success factors of project and process management for the implementation of competitive strategy.
The study contributes to the academic scenario as a source for research in the line of strategy and competitiveness and as a mean to explore the theories around the parallel use of two management methods in order to achieve a successful competitive strategy implementation. For companies, the contribution is because it organizes a scheme that ranks the relevance of requirements for the implementation of competitive strategy that can support companies in promoting actions to adapt the corporate environment so that all of productive links are aligned with the strategic objectives.

\section{LITERATURE REVIEW}

\section{The evolution of the vision on strategy and competitiveness}

Competitive advantage is a topic that has been explored by many authors over the years. Nalebuf and Brandenburger (1996) deal with the concept of coopetition, a business strategy that combines both cooperation and competition, that is, companies complement each other by creating the market and competing by dividing it. Silva and Villan (2018) point out that this type of strategy creates competitive advantage by promoting the search for otherwise inaccessible resources.

For Brown and Eisenhardt (1998), the organization must keep its old business in balance with innovations, explore past experience for business creation and revitalization, and delve into novelty and randomness to suit unpredictability and rapid change. Kelm et al. (2014) reinforce the role of innovation in the competitive landscape of organizations to turn opportunities into advantage for the company.

Hax and Wilde (2001) highlight in the business model the opportunities arising from the creation of a connection with the customer through the construction of a market position based on low costs or product differentiation, development of value propositions to connect to each individual and the guarantee of indisputable leadership in the market, achieved by the complete analysis of the whole configuration of the network of interconnections, company, consumers, suppliers, and complementary.

For Barney (2002), the company leverages its competitive advantage when it has the resources and capabilities: that respond positively to threats and weaknesses, creating value for the company; that are controlled by a small number of competitors, and is considered rarity in the market; that faces some cost disadvantage in order to obtain or develop them, and is therefore difficult to imitate and; whose company policies and procedures support the exploration of the 
issues value, rarity and imitability, referring to a sense of organization in the company.

On the other hand, Kim and Mauborgne (2005) point to the blue ocean environment as a form of competitive advantage, a position reached when one crosses the frontiers of competition in unexplored business spaces, whose growth is highly profitable and arises from the very creation from the demand of establishing value creation with innovation, thus pursuing differentiation and leadership in cost at the same time. Xavier et al. (2015) studied a practical example of using this strategy through research carried out with customers of an electronic service company that maintains the differential in its business by offering a personalized service with home delivery and still manages to have cost leadership by not using stocks in its operation.

Longoni and Cagliano (2015) point out another competitive differential in terms of sustainability. Environment and social priorities complement market-oriented operations strategies, that is, the balance of the sustainable approach with the traditional quality, delivery and innovation approaches tends to perform better in the short-term financial aspect and in the operational and sustainable aspects in the long term, providing an improvement in terms of competitive position.

Technology progress has enabled organizations to have a maximized ability to collect vast amounts of data (Big Data). However, with shorter periods in the life cycle of products and services, care must be taken with the quality of what is extracted from the information of these sources. Thus, the ability to analyze significant and relevant data, influencing the company to transform the acquired knowledge into structured actions, is the key to the competitive differential (Bumblauskas et al., 2017).

In view of this explicit framework, it is observed that competitiveness in organizations has promoted the need to advance in theoretical and practical fields in order to establish the best tactics so that companies can stand out from the competition.

\section{Implementing the strategy through processes and projects}

Assuming the need to guide the actions of the organization to achieve the defined strategic objectives and improve performance through rational use of resources requires an understanding of the dynamics of the company's relationship with its environment (Ronda-Pupo and Guerra-Martin, 2012). In this way, the conversion of the strategic plan into a daily management element involves a dynamic system of communication, an assertive unfolding of objectives in all key processes, active participation and employee engagement, and continuous performance monitoring (Suarez et al., 2016).

Leveraging a successful business transformation requires a change management process, encompassing a business vision, organizational strategy, and strong and empowered leadership, elements that must be connected by the process management and organized systems (Kim, 2007). It is also noted that corporate success increases when the company strives to be business process oriented. To this end, it counts on the support of the top management to ensure adequacy between the strategy and the events of the company environment, with the capacity to change its processes when necessary, with the alignment of the technology to the tasks, and with the training and means of diffusion among employees, in order to understand their role in the process (Škrinjar and Trkman, 2013).

For the Association of Business Process Management Professionals (ABPMP, 2013) process can be define as "an aggregation of activities and behaviors performed by humans or machines to achieve one or more results", delivering value to clients or supporting / managing other processes. Process management contributes to a more holistic view of the company's processes by using an integrated set of corporate capabilities in order to analyze, design, implement, continuously improve, and innovate organizational processes disruptively (Brocke and Mendling, 2017).

According to Brocke and Rosemann (2010), processes have to be aligned with the corporate strategy, "linkage of organizational priorities and enterprise processes, enabling continual and effective action to improve business performance". In this way, the authors reinforce that it is necessary to extract the process improvement plan from strategy, in order to understand the bidirectional relationship between processes and strategy, providing a convergence between them and to define and follow performance indicators, and links between processes and strategic goals.

In order to help organizations implement their goals, another method that can be used in parallel is project management. For the Project Management Institute (PMI, 2014), project is the "temporary effort undertaken to create a unique product, service and result" and it is only considered successful by aligning itself with strategic objectives (Awwal, 2014). However, it is important to be aware that one of the challenges of all organizations is concerned with improving the efficiency and effectiveness of their projects to consolidate a management culture (Scotelano et al., 2017).

In this sense, the implementation rate of the strategy tends to improve through project portfolio management (Buys and Stander, 2010), supporting companies to achieve 
better results, even with increasingly scarce resources. It is perceived that an effective project portfolio management can provide support in a structured and organized way in order to select only projects capable of generating competitive advantage, the organizations' desire to excel in the market (Carvalho et al., 2013).

Furthermore, it should be highlighted that process and project management also complement each other. Process management can be implemented using project concepts, "specific initiative or a project to improve process alignment and performance with organizational strategy and customer expectations" (ABPMP, 2013). And for project management, besides being composed of work processes, process orientation can provide support to achieve "process thinking" in project management, thereby promoting the opportunity to control and support learning activities, while the objectives of support processes and systems facilitate the management of information (Chronéer and Backlund, 2015).

In summary, as can be observed in the literature review, there is a synergy between the subjects of strategy, process management and project management, whose summary of the main points is shown in table 1.

\section{METHODOLOGY}

In order to achieve the objectives of the study, the research used a questionnaire based on the theories involved in competitive strategy, project management and process management. The bibliometric research followed four steps: keyword identification, database creation, article analyses, and article selection. In the first step, the terms chosen were "Strategy", "Process Management", "Project Management", and "Competitive Advantage", and to maximize the options, the connectors "AND", joint search of the terms, and "OR" were used. In the second step, a data base was created with all the names of articles found in the research, where the duplicated ones were eliminated. After that, an analysis of the articles' abstracts' were done in order to identify and select the ones connected with the studies.

The survey was applied electronically from July $4^{\text {th }}, 2018$ to August $4^{\text {th }}, 2018$ in Linkedln groups in synergy with the study topic, and it was also sent to a base of four hundred experts in projects and processes and resulted in 71 responses with the desired profile, that is, professionals with at least five years of experience in the fields related to process management or project management. It is important to emphasize that, before being applied, six specialists, with at least five years of experience in projects and processes, analyzed the content of the instrument and contributed to the result applied, which was qualitative validation.

It is a nonparametric sample, "model that only presents very general conditions, without specifying the distribution from which the sample was extracted and that can be used for the analysis of data classified in categories" (Siegel and Castellan, 2006) and it is a convenience sample, because, according to Fink (2005), it uses the most conveniently available people as participants.

Table 1. Insights from Literature

\begin{tabular}{|c|c|}
\hline Topics & Main points \\
\hline Competitive strategy success & $\begin{array}{l}\text { Coopetition, a business strategy that combines both cooperation and competition } \\
\text { Balance between traditional and innovation } \\
\text { Connection with the customer through the construction of a market position based on low costs or } \\
\text { product differentiation } \\
\text { Focus in value, rarity, imitability and organization } \\
\text { The creation of demand establishes value creation with innovation, thus pursuing differentiation and } \\
\text { leadership in cost at the same time } \\
\text { Care must be taken in the quality of what is extracted in data } \\
\text { Balance of the sustainable approach with the traditional approach }\end{array}$ \\
\hline $\begin{array}{l}\text { Alignment between process } \\
\text { management and strategy }\end{array}$ & $\begin{array}{l}\text { Delivering value to clients and other processes } \\
\text { Holistic view } \\
\text { Analyze, design, implement, continuously improve, and disruptively innovate organizational processes } \\
\text { Process alignment with strategy } \\
\text { Follow up performance indicators }\end{array}$ \\
\hline $\begin{array}{l}\text { Alignment between project } \\
\text { management and strategy }\end{array}$ & $\begin{array}{l}\text { Implementation of the strategic plan } \\
\text { Selection of projects capable of generating competitive advantage } \\
\text { Projects are only successful when their goals are connected to the strategic goals }\end{array}$ \\
\hline $\begin{array}{l}\text { Alignment between process } \\
\text { management and project } \\
\text { management }\end{array}$ & $\begin{array}{l}\text { Implementation of process improvement plan using project management } \\
\text { Promoting the opportunity to control and support learning activities by process orientation in project } \\
\text { management }\end{array}$ \\
\hline
\end{tabular}


The instrument was developed based on a Likert scale, intended to assess the degree of relevance (Nothing relevant, not very relevant, fairly relevant, very relevant, and totally relevant) of the requirements raised in the literature as critical factors for the successful implementation of the competitive strategy and identify new critical factors through the perception of market experts.

For data treatment, after tabulating the data collected through the research instrument, were used, respectively, relative frequency and mode, the number of items of each class by the number of elements observed and the most frequently occurring value (Sweeney et al., 2015).

\section{ANALYSIS OF RESULTS}

First, it is important to mention that, to facilitate the analysis, the requirements of the research instrument raised from the literature were codified, as can be seen in Table 2 .

Table 2. Encoding search requirements

\begin{tabular}{|c|c|}
\hline ID & Requirements \\
\hline R1 & Follow-up of process performance indicators \\
\hline $\mathrm{R} 2$ & Competition analysis \\
\hline R3 & $\begin{array}{l}\text { Analysis of the external environment of the organization } \\
\text { in the economic, social and political aspects }\end{array}$ \\
\hline R4 & Structured value chain of organizational processes \\
\hline R5 & Communication of the strategic vision \\
\hline R6 & Coordination and communication in projects \\
\hline R7 & Definition of roles and responsibility in processes \\
\hline R8 & Definition of roles and responsibility in projects \\
\hline R9 & Employees' engagement \\
\hline R10 & $\begin{array}{l}\text { Deliveries of the organizational projects integrated with } \\
\text { the existing processes in the company }\end{array}$ \\
\hline R11 & $\begin{array}{c}\text { Balance of the number of projects in } \\
\text { the company portfolio } \\
\end{array}$ \\
\hline R12 & Balance of financial, social and environmental aspects \\
\hline R13 & $\begin{array}{l}\text { Focus on profitability } \\
\end{array}$ \\
\hline R14 & Focus on productivity \\
\hline R15 & Focus on reliability of products and services \\
\hline R16 & Customer focus \\
\hline R17 & Organizational risk management \\
\hline R18 & Quality management \\
\hline R19 & Data and information management \\
\hline R20 & Change management \\
\hline $\mathrm{R} 21$ & Project time management \\
\hline $\mathrm{R} 22$ & Knowledge management \\
\hline $\mathrm{R} 23$ & Project portfolio management \\
\hline $\mathrm{R} 24$ & Project management guided by strategic objectives \\
\hline R25 & Governance and compliance \\
\hline R26 & Innovation in balance with existing company experience \\
\hline R27 & Committed leadership \\
\hline
\end{tabular}

\begin{tabular}{|c|c|}
\hline R28 & Process mapping and modeling \\
\hline R29 & Maximizing the use of organizational resources \\
\hline R30 & Continuous process improvement \\
\hline R31 & Structured project management methodology \\
\hline R32 & Structured process management methodology \\
\hline R33 & Formal strategic planning process \\
\hline R34 & $\begin{array}{c}\text { Flexible and adaptable processes to } \\
\text { change market demands }\end{array}$ \\
\hline R35 & Processes guided by strategic objectives \\
\hline R36 & Standardized and uniform processes \\
\hline R37 & $\begin{array}{l}\text { Promoting an integrated and holistic view } \\
\text { of the organization }\end{array}$ \\
\hline R38 & Promoting teamwork \\
\hline R39 & Value proposition based on innovation \\
\hline R40 & Reduction of operation cost \\
\hline R41 & Reduction of process execution times \\
\hline R42 & Selection of projects guided by strategic objectives \\
\hline
\end{tabular}

In order to identify the perception of the 71 respondents about the relevance of the research requirements as critical success factors in the implementation of a competitive strategy, the analysis of the relative frequency of each of the 42 requirements raised in the literature was applied, also identifying the percentage of mode and the position in the corresponding Likert scale. This result can be seen in Table 3.

Analyzing the zone of positive relevance, Totally and Very Relevant, as observed in Figure 1, the lowest value was $64.29 \%$, R13 - Focus on profitability, and the highest, with 98.59\%, was R9 - Employees' engagement. Thus, all the requirements identified in the literature and aligned with at least one of the focus themes of research, strategy, process management or project management, were confirmed by the respondents' perception as critical success factors for competitive strategy implementation. This fact endorsed the influence of process management and project management to implement a successful competitive strategy.

To rank the requirements by mode, in each of the three groups, "Totally Relevant", "Totally Relevant and Very Relevant" and "Very Relevant", a classification from the highest importance to the minor was made. Thus, the result of this rank can be observed in Figure 2, noting that the list had thirty-five positions, since the cases with equal percentage values within each group were allocated in the same place of classification. It is worth mentioning that, from the first position to the twentieth, the group is the "Totally Relevant", the twenty-first place is "Totally Relevant and Very Relevant" and from the twenty second on is the "Very Relevant" group.

The result of relevance ordering for the 42 requirements showed that by the perception of the respondents, requirement R16 - Customer Focus, is the most important when thinking about a competitive strategy implementation. This 
Table 3. Relative Frequency and Mode

\begin{tabular}{|c|c|c|c|c|c|c|c|}
\hline $\begin{array}{c}\text { ID } \\
\text { Requirement }\end{array}$ & $\begin{array}{l}\text { Nothing } \\
\text { Relevant }\end{array}$ & $\begin{array}{l}\text { Not very } \\
\text { Relevant }\end{array}$ & $\begin{array}{c}\text { Fairly } \\
\text { Relevant }\end{array}$ & $\begin{array}{c}\text { Very } \\
\text { Relevant }\end{array}$ & $\begin{array}{c}\text { Totally } \\
\text { Relevant }\end{array}$ & $\%$ Mode & \% Mode Position \\
\hline $\mathrm{R} 1$ & $0,00 \%$ & $0,00 \%$ & $4,23 \%$ & $29,58 \%$ & $66,20 \%$ & $66,20 \%$ & Totally Relevant \\
\hline $\mathrm{R} 2$ & $0,00 \%$ & $7,14 \%$ & $14,29 \%$ & $42,86 \%$ & $35,71 \%$ & $42,86 \%$ & Very Relevant \\
\hline R3 & $0,00 \%$ & $2,86 \%$ & $18,57 \%$ & $34,29 \%$ & $44,29 \%$ & $44,29 \%$ & Totally Relevant \\
\hline $\mathrm{R} 4$ & $0,00 \%$ & $0,00 \%$ & $20,00 \%$ & $32,86 \%$ & $47,14 \%$ & $47,14 \%$ & Totally Relevant \\
\hline R5 & $0,00 \%$ & $1,43 \%$ & $7,14 \%$ & $28,57 \%$ & $62,86 \%$ & $62,86 \%$ & Totally Relevant \\
\hline $\mathrm{R} 6$ & $0,00 \%$ & $0,00 \%$ & $7,14 \%$ & $38,57 \%$ & $54,29 \%$ & $54,29 \%$ & Totally Relevant \\
\hline R7 & $0,00 \%$ & $1,41 \%$ & $4,23 \%$ & $36,62 \%$ & $57,75 \%$ & $57,75 \%$ & Totally Relevant \\
\hline R8 & $0,00 \%$ & $1,41 \%$ & $5,63 \%$ & $40,85 \%$ & $52,11 \%$ & $52,11 \%$ & Totally Relevant \\
\hline R9 & $0,00 \%$ & $0,00 \%$ & $1,41 \%$ & $22,54 \%$ & $76,06 \%$ & $76,06 \%$ & Totally Relevant \\
\hline R10 & $0,00 \%$ & $1,41 \%$ & $11,27 \%$ & $36,62 \%$ & $50,70 \%$ & $50,70 \%$ & Totally Relevant \\
\hline R11 & $1,41 \%$ & $1,41 \%$ & $28,17 \%$ & $46,48 \%$ & $22,54 \%$ & $46,48 \%$ & Very Relevant \\
\hline R12 & $0,00 \%$ & $1,41 \%$ & $23,94 \%$ & $49,30 \%$ & $25,35 \%$ & $49,30 \%$ & Very Relevant \\
\hline R13 & $0,00 \%$ & $5,71 \%$ & $30,00 \%$ & $38,57 \%$ & $25,71 \%$ & $38,57 \%$ & Very Relevant \\
\hline R14 & $0,00 \%$ & $0,00 \%$ & $11,27 \%$ & $49,30 \%$ & $39,44 \%$ & $49,30 \%$ & Very Relevant \\
\hline R15 & $0,00 \%$ & $0,00 \%$ & $8,45 \%$ & $38,03 \%$ & $53,52 \%$ & $53,52 \%$ & Totally Relevant \\
\hline R16 & $0,00 \%$ & $1,45 \%$ & $4,35 \%$ & $14,49 \%$ & $79,71 \%$ & $79,71 \%$ & Totally Relevant \\
\hline R17 & $0,00 \%$ & $4,23 \%$ & $16,90 \%$ & $47,89 \%$ & $30,99 \%$ & $47,89 \%$ & Very Relevant \\
\hline R18 & $0,00 \%$ & $1,41 \%$ & $14,08 \%$ & $47,89 \%$ & $36,62 \%$ & $47,89 \%$ & Very Relevant \\
\hline R19 & $0,00 \%$ & $4,35 \%$ & $7,25 \%$ & $47,83 \%$ & $40,58 \%$ & $47,83 \%$ & Very Relevant \\
\hline R20 & $0,00 \%$ & $1,43 \%$ & $10,00 \%$ & $42,86 \%$ & $45,71 \%$ & $45,71 \%$ & Totally Relevant \\
\hline $\mathrm{R} 21$ & $1,41 \%$ & $2,82 \%$ & $7,04 \%$ & $57,75 \%$ & $30,99 \%$ & $57,75 \%$ & Very Relevant \\
\hline $\mathrm{R} 22$ & $0,00 \%$ & $0,00 \%$ & $18,57 \%$ & $45,71 \%$ & $35,71 \%$ & $45,71 \%$ & Very Relevant \\
\hline $\mathrm{R} 23$ & $1,43 \%$ & $1,43 \%$ & $22,86 \%$ & $44,29 \%$ & $30,00 \%$ & $44,29 \%$ & Very Relevant \\
\hline R24 & $0,00 \%$ & $2,90 \%$ & $2,90 \%$ & $37,68 \%$ & $56,52 \%$ & $56,52 \%$ & Totally Relevant \\
\hline $\mathrm{R} 25$ & $0,00 \%$ & $1,43 \%$ & $17,14 \%$ & $40,00 \%$ & $41,43 \%$ & $41,43 \%$ & Totally Relevant \\
\hline $\mathrm{R} 26$ & $0,00 \%$ & $0,00 \%$ & $12,86 \%$ & $50,00 \%$ & $37,14 \%$ & $50,00 \%$ & Very Relevant \\
\hline $\mathrm{R} 27$ & $0,00 \%$ & $0,00 \%$ & $4,35 \%$ & $21,74 \%$ & $73,91 \%$ & $73,91 \%$ & Totally Relevant \\
\hline $\mathrm{R} 28$ & $0,00 \%$ & $1,43 \%$ & $24,29 \%$ & $37,14 \%$ & $37,14 \%$ & $37,14 \%$ & $\begin{array}{c}\text { Totally Relevant and } \\
\text { Very Relevant }\end{array}$ \\
\hline R29 & $0,00 \%$ & $1,41 \%$ & $19,72 \%$ & $40,85 \%$ & $38,03 \%$ & $40,85 \%$ & Very relevant \\
\hline R30 & $0,00 \%$ & $1,41 \%$ & $12,68 \%$ & $30,99 \%$ & $54,93 \%$ & $54,93 \%$ & Totally Relevant \\
\hline R31 & $1,41 \%$ & $1,41 \%$ & $14,08 \%$ & $52,11 \%$ & $30,99 \%$ & $52,11 \%$ & Very Relevant \\
\hline R32 & $0,00 \%$ & $1,41 \%$ & $15,49 \%$ & $46,48 \%$ & $36,62 \%$ & $46,48 \%$ & Very Relevant \\
\hline R33 & $0,00 \%$ & $1,43 \%$ & $27,14 \%$ & $44,29 \%$ & $27,14 \%$ & $44,29 \%$ & Very Relevant \\
\hline R34 & $0,00 \%$ & $0,00 \%$ & $5,80 \%$ & $37,68 \%$ & $56,52 \%$ & $56,52 \%$ & Totally Relevant \\
\hline R35 & $0,00 \%$ & $0,00 \%$ & $10,14 \%$ & $27,54 \%$ & $62,32 \%$ & $62,32 \%$ & Totally Relevant \\
\hline R36 & $0,00 \%$ & $2,82 \%$ & $23,94 \%$ & $47,89 \%$ & $25,35 \%$ & $47,89 \%$ & Very Relevant \\
\hline R37 & $0,00 \%$ & $4,41 \%$ & $17,65 \%$ & $36,76 \%$ & $41,18 \%$ & $41,18 \%$ & Totally Relevant \\
\hline R38 & $0,00 \%$ & $0,00 \%$ & $7,14 \%$ & $40,00 \%$ & $52,86 \%$ & $52,86 \%$ & Totally Relevant \\
\hline R39 & $0,00 \%$ & $1,43 \%$ & $22,86 \%$ & $45,71 \%$ & $30,00 \%$ & $45,71 \%$ & Very Relevant \\
\hline $\mathrm{R} 40$ & $1,41 \%$ & $1,41 \%$ & $22,54 \%$ & $45,07 \%$ & $29,58 \%$ & $45,07 \%$ & Very Relevant \\
\hline R41 & $0,00 \%$ & $1,41 \%$ & $25,35 \%$ & $42,25 \%$ & $30,99 \%$ & $42,25 \%$ & Very Relevant \\
\hline R42 & $0,00 \%$ & $0,00 \%$ & $5,80 \%$ & $36,23 \%$ & $57,97 \%$ & $57,97 \%$ & Totally Relevant \\
\hline
\end{tabular}


Brazilian Journal of Operations \& Production Management Volume 16, Número 4, 2019, pp. 605-616 DOI: 10.14488/BJOPM.2019.v16.n4.a6

\begin{tabular}{|c|c|c|c|c|c|}
\hline R1 & R8 & R15 & R22 & R29 & R36 \\
\hline $95,77 \%$ & $92,96 \%$ & $91,55 \%$ & $81,43 \%$ & $78,87 \%$ & $73,24 \%$ \\
\hline R2 & R9 & R16 & R23 & R30 & R37 \\
\hline $78,57 \%$ & $98,59 \%$ & $94,20 \%$ & $74,29 \%$ & $85,92 \%$ & $77,94 \%$ \\
\hline R3 & R10 & R17 & R24 & R31 & R38 \\
\hline $78,57 \%$ & $87,32 \%$ & $78,87 \%$ & $94,20 \%$ & $83,10 \%$ & $92,86 \%$ \\
\hline R4 & R11 & R18 & R25 & R32 & R39 \\
\hline $80,00 \%$ & $69,01 \%$ & $84,51 \%$ & $81,43 \%$ & $83,10 \%$ & $75,71 \%$ \\
\hline R5 & R12 & R19 & R26 & R33 & R40 \\
\hline $91,43 \%$ & $74,65 \%$ & $88,41 \%$ & $87,14 \%$ & $71,43 \%$ & $74,65 \%$ \\
\hline R6 & R13 & R20 & R27 & R34 & R41 \\
\hline $92,86 \%$ & $64,29 \%$ & $88,57 \%$ & $95,65 \%$ & $94,20 \%$ & $73,24 \%$ \\
\hline R7 & R14 & R21 & R28 & R35 & R42 \\
\hline $94,37 \%$ & $88,73 \%$ & $88,73 \%$ & $74,29 \%$ & $89,86 \%$ & $94,20 \%$ \\
\hline
\end{tabular}

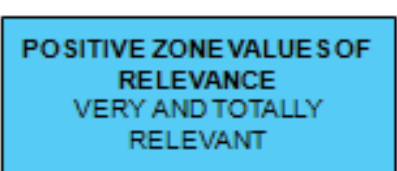

RELEVANT
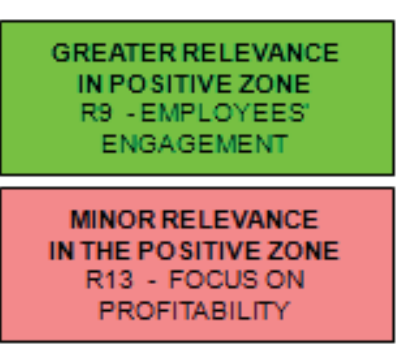

Figure 1. Positive relevance zone analysis

Source: Authors themselves

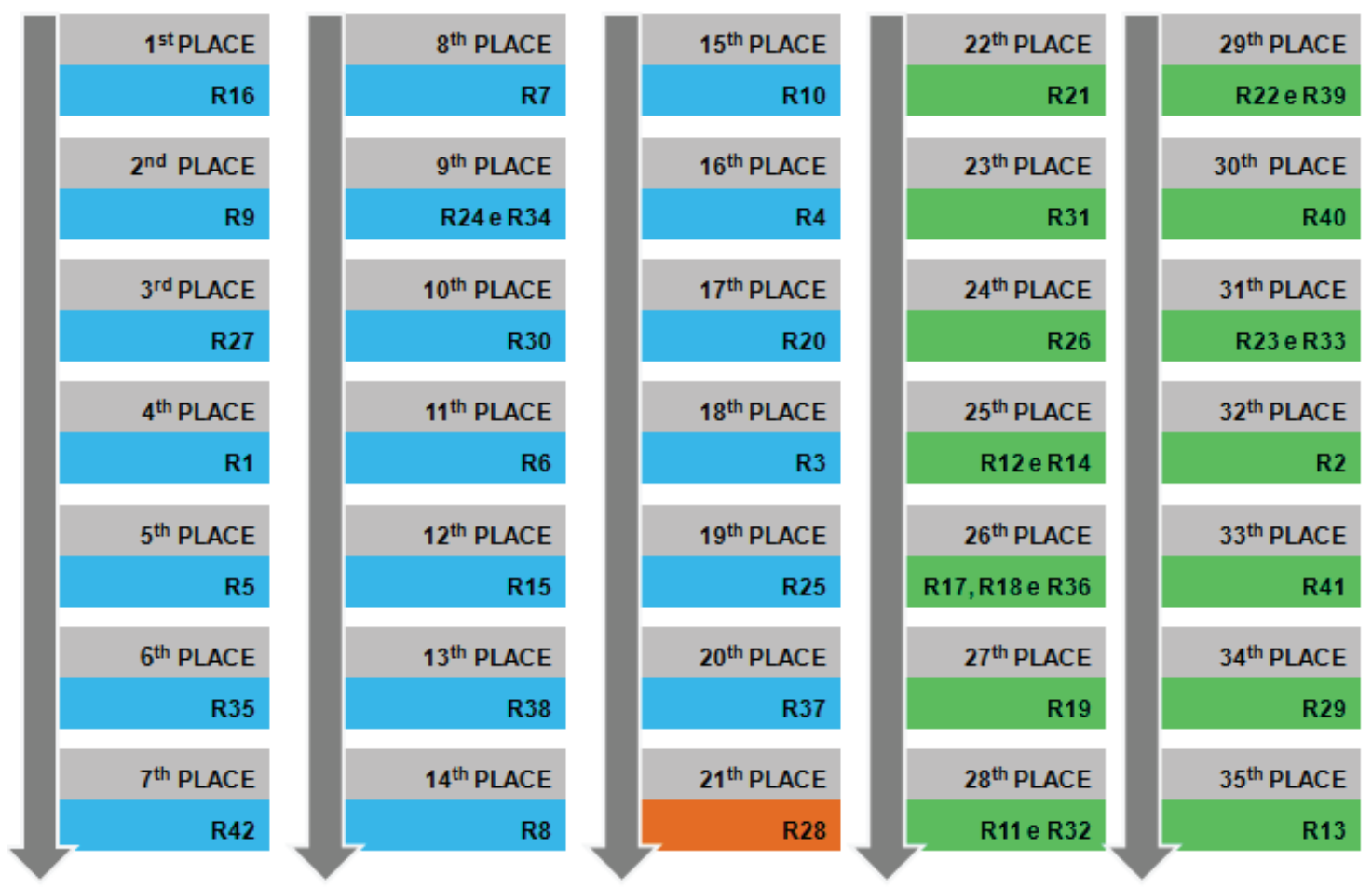

Figure 2. Ranking of requirements by relevance and frequency Source: Authors themselves 
Brazilian Journal of Operations \& Production Management

Volume 16, Número 4, 2019, pp. 605-616

DOI: 10.14488/BJOPM.2019.v16.n4.a6 fact reinforces the idea that the client should guide the direction of the company and, therefore, it is essential to promote practices aimed at listening to them.

It should be noted that the second and third place of this map, R9 - Employees' Engagement and R27 - Committed Leadership, corroborates to validate how human capital is seen as essential for the competitiveness of an organization. In the foreground, companies need the team to be motivated so that all processes work perfectly, and for this, leadership has the role of encouraging employees through words and, especially their attitudes and actions.

The fourth place, R1 - Follow-up of process performance indicators, fosters the view that it is necessary to monitor the performance of the companies, and it is the opportunity to have assertive decision making in a timely manner, in the event of any changes in the established strategy.

The fifth position of relevance, R5 - Communication of the strategic vision, demonstrates the importance of the respondents' perception that all employees should know the direction of the company, a way of establishing a collective census of commitment and understanding regarding what should really be prioritized and orchestrated within the company, so it can achieve its goals.

The other assignments of the Totally Relevant group address the following requirements: R35 - Processes oriented by strategic objectives; R42 - Selection of projects guided by strategic objectives; R7 - Definition of roles and responsibility in the processes; R24 - Project management guided by strategic objectives; R34 - Flexible and adaptable processes to changing market demands; R30 - Continuous process improvement; R6 - Coordination and communication in projects; R15 - Focus on product and service reliability; R38 - Promotion of teamwork; R8 - Definition of roles and responsibility in projects; R10 - Deliveries of the organizational projects integrated with the existing processes in the company; R4 - Structured organizational process value chain; R20 - Change management; R3 - Analysis of the environment external to the organization in economic, social and political aspects; R25 - Governance and compliance; and R37 - Promotion of an integrated and holistic view of the organization.

The twenty-first position, requirement R28 - Processes mapping and modeling, is a transition line between the totally relevant and very relevant group and points to the need to know the processes performed by the organization as an item whose degree of relevance was tied to the perception of the respondents, some framing this requirement as more essential than others.
In the very relevant group, from the twenty-second to the thirty-fourth position, the requirements presented were: R21 - Time management of projects; R31 - Structured project management methodology; R26 - Innovation in balance with existing company experience; R12 - Balance of financial, social and environmental aspects; R14 - Focus on productivity; R17 - Organizational risk management; R18 - Quality management; R36 - Standardized and uniform processes; R19 - Data and information management; R11 Balance of the number of projects in the company portfolio; R32 - Structured process management methodology; R22 Knowledge management; R39 - Value proposition based on innovation; R40 - Reduction of operation cost; R23 - Project portfolio management; R33 - Formal strategic planning process; R2 - Competition analysis; R41 - Reduction of process execution times; and R29 - Maximizing the use of organizational resources.

In the last place is the requirement R13 - Focus on profitability, which, despite being very relevant among the 42 options, was indicated by the perception of the respondents as the least essential for the organization. This view can be justified by the fact that such thinking is more difficult to be the focus of employee action, thus being a consequence of their activities and probably a major concern in the top-ranking positions.

To identify in the market specialists' opinion other critical success factors for competitive strategy implementation, a content analysis of each response was performed, eliminating those without relevant information to the study, verifying those that were in synergy with what had already been found in the literature, and identifying the new critical success factors raised by the experts.

The result was the identification of 12 new critical success factors: NR1 - Decentralized management with reduced bureaucracy in processes; NR2 - Effective selection of employees; NR3 - Valuation and employee retention; NR4 - Structuring of management methods; NR5 - Technology investment; NR6 - Organizational structure; NR7 - Business planning and focus; NR8 - Alignment between stakeholders' needs and strategic objectives; NR9 - Financial Management; NR10 Alignment of strategy, projects, processes and technology; NR11 - Project and process maturity evaluation; and NR12 Deployment of strategic objectives in individual goals.

Some respondents expressed concern regarding the collaborator, citing as relevant: the process of selection and retention of talent, development of resources through training and mentoring, establishment of meritocracy policies, motivational encouragement through an organizational culture for that purpose, and the application of training focused on projects and processes of the company and alignment between these two pillars to that of people. 
Thus, the addition of three new items related to employees can be observed: NR2 - Effective selection of employees; NR3 - Valuation and retention of employees; and NR12 - Deployment of strategic objectives in individual goals. This fact is also in line with the relevance ranking of Figure 2, since R9 - Employees' Engagement was the second position. Thus, in order to motivate employees, the company plays an important role in the selection of professionals in line with its objectives and values, and then it is up to it to promote valuation and retention practices linked to individual performance, as the examples of merit recognition and constant investment in employee improvement.

In terms of processes, a vision was presented regarding their process-oriented form of governance, with reduced bureaucracy and even with a decentralization bias. In addition, it was also mentioned the need to structure a process office and to monitor process maturity to direct actions within the company, as well as quantitative models, aiming at the continuous improvement of synergy with the full knowledge of the business and its operation. They also signaled the need for mapping and documentation, leveraging these records as well as lessons learned from projects and processes. In view of this, the new critical success factors were created: NR1 - Decentralized management with reduced bureaucracy in processes; NR4 - Structuring of management methods; and NR11 - Project and process maturity evaluation.

About the organization, the respondents mentioned as essential: the alignment of the company's needs with a vision of the future, the understanding of stakeholders, adequate financial management, a vision on how the company is structured, the direction and focus on the strategic actions and their deployment in projects and processes. In view of this framework, the following new critical success factors were structured: NR6 - Organizational structure; NR7 - Business planning and focus; NR8 - Alignment between stakeholders' needs and strategic objectives; and NR9 - Financial Management.

Finally, in line with the technological advances of recent times, some respondents have pointed to technology as a relevant means for successful competitive strategy implementation and even pointed to the integration of projects, processes, technology and strategy. This fact fostered the inclusion of new critical success factors: NR5 - Technology investment; and NR10 - Alignment of strategy, projects, processes, and technology.

\section{DISCUSSION AND IMPLICATIONS}

It can be noticed that, besides the three focus elements of the study, strategy, processes and projects, another theme stood out in this analysis: people. This view was evident in the group's perception of the orderly ranking of relevance and the new critical success factors identified. Thus, people can be in the figure of customer or workforce, in leadership positions and led roles.

This means that, by the result of the analysis of the researched scenario, in addition to these pillars of strategy, processes and projects, people have gained prominence as a relevant item for strategic implementation, so they need to be included as one of the bases for competitive advantage, which can be observed in Figure 3 that shows the modification in the original pillar of the survey.

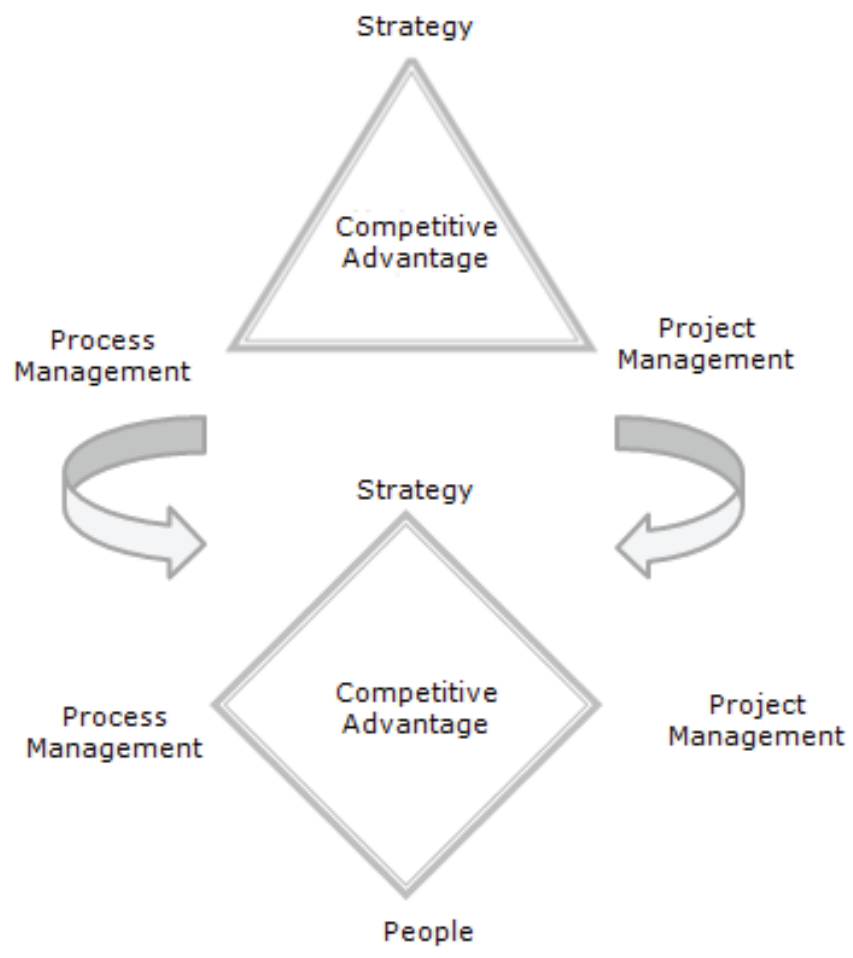

Figure 3. Modification in the original pillars of the research Source: Authors themselves

The scenario studied shows that implementing a successful competitive strategy requires a significant effort from the organization, since its success is made up of a diverse set of factors, as could be verified during the analysis of the research. Therefore, it is recommended that organizations adopt the following guidelines:

\section{a) Elaborate the organizational strategy focused on your client;}

Targeting the focus of the organization to be more assertive is imperative in an increasingly fierce competition and, as it could be observed in the research, this focus should be the customer. With this, the identification of the target pub- 
lic of the company is firstly determined, so that the profile of this group can be analyzed and understood, and, based on this input, promote the creation of solutions that generate value for these consumers.

In addition, in order to have a more satisfying response in the strategic plan, it is important to understand what the market is offering to the audience and how it is accepted. Thus, the competition analysis is done from the perspective of what the customer is looking for in other companies. It is also necessary to have a vision of the business environment both externally and internally to verify whether all the idealized plans can be made possible.

With the knowledge of what customers want, how the competition responds and how the environment tends to respond to the actions of the organization, the strategic plan must be elaborated and subsequently deployed at all levels of the company.

\section{b) Maintain an assertive and engaged staff framework;}

To materialize the strategic plan, developed with a focus on the client, it is essential that the staff is adherent to the objectives of the company, with committed and motivated employees for corporate success. This demand requires assertive selections of leadership and led positions, remuneration and performance policies aligned with the market, employee appreciation actions, and other good people management practices. In addition, the group must be guided and the organization's strategy must communicated so that its functions are aligned with the needs of the company.

\section{c) Monitor the performance of your strategic objectives;}

In order to anticipate eventual deviations from the path established by the organization, strategic objectives must be accompanied by performance indicators, which, when monitoring the company, allow proactive and anticipated adjustments by analyzing trends in the behavior of the historical series of results.

For this to be possible, it is fundamental that the strategy is deployed in the company's processes and projects. As such, processes must ensure deliveries within their specifications and have the flexibility to meet market needs. Projects, however, need to be selected to ensure results aligned with the direction of the company and not only to occasional opportunities that may arise.

\section{d) Integrate the company's management system through its strategy.}

As could be observed in the research, all requirements raised in the literature were considered as critical success factors and, in addition, others were included by the group. This fact corroborates to show that, in order to be competitively successful, the organization should function as an integrated and cohesive system, with the unfolding of company management, aligning the management practices with the strategic objectives.

\section{CONCLUSION}

To answer the survey, an analysis of frequency of the questionnaire responses prepared with 42 requirements raised in the literature identified the relevance of each requirement, confirming that all were considered critical success factors. In addition, through the mode, the relevance ranking of these items was presented as the three most relevant: R16 - Customer focus; R9 - Employees' engagement; and R27 - Committed leadership. Besides that, by analyzing the responses of the studied group, 12 critical success factors most important for the implementation of competitive strategy were extracted.

Faced with the analysis, the present work collaborates to recommend as a guide to companies four priority actions and identify that, from the perception of the studied group, besides the three focus elements of the study, strategy, processes and projects, that the subject matter people had a great prominence with both notes referring to the client as well as the workforce, leadership and led roles. In other words, in addition to the strategy pillars processes and projects, people need to be included as one of the bases for competitive advantage.

Among the limitations presented in the project, one can be highlighted, the size of the sample, which was conditioned to the number of respondents of the questionnaire distributed by electronic means. And because the size of the population is unknown, it is not possible to realize generalizations.

The research contributes academically by presenting content that can serve as a source of future studies in synergy with the themes strategy, processes, projects and competitiveness. It is also significant for the market, since organizational leaders can, based on the perceptions of the analyzed group, promote adaptations in the corporate environment by understanding the guiding recommendations and degree of relevance of the critical success factors for the implementation of a competitive strategy that can be input for prioritizing actions within the company. 
Finally, it is suggested for future projects: a study to evaluate which of the critical success factors for the implementation of a competitive strategy has effectively been carried out by the companies and which have been successful; the application of the questionnaire in an English version for foreign professionals for comparison with the perception of this group, in order to understand whether there is similarity in the national and international scope; and case studies could be carried out in companies from different segments to compare the scenario found with the practices of organizations.

\section{REFERENCES}

Anholon, R.; Silva, D.; Quelhas, O. L. G. (2017), “Main causes that lead strategies to decline at execution phase: an analysis of Brazilian companies", International Journal of Productivity and Performance Management, Vol. 66, No. 3, pp. 426-440. https://doi.org/10.1108/IJPPM-09-2015-0126

Association of Business Process Management Professionals (2013), BPM CBOK: guia de processos de negócio corpo comum de conhecimento ABPMP BMP CBOK V3.0, Association of Business Process Management Professionals, Chicago.

Awwal, M. I. (2014), "Importance of strategic aspect in project management: a literature critique", International Journal of Supply Chain Management, Vol. 3, No. 4, pp. 96-99, available from: http://citeseerx.ist.psu.edu/viewdoc/download?do $i=10.1 \cdot 1.666 .6573 \&$ rep=rep1\&type=pdf (access March 2017)

Barney, J. B. (2002), Gaining and sustaining competitive advantage (2nd ed.), Prentice Hall, New Jersey.

Brocke, J. vom.; Mendling, J. (2017), “Frameworks for Business Process Management: A Taxonomy for Business Process Management Cases", Business Process Management Cases, Vol. 1, pp. 1-17. https://doi.org/10.1007/978-3-319-583075_1

Brocke, J. vom.; Rosemann, M. (2010), Handbook on business process management 1: introduction, methods, and information systems, Springer, Berlin Heidelberg.

Brown, S.; Eisenhardt, K. (1998), Competing on the edge: strategy as structured chaos, Harvard Business School Press, Boston.

Bumblauskas, D.; Nold, H.; Bumblauskas, P. et al. (2017), "Big data analytics: transforming data to action", Business Process Management Journal, Vol. 23, No. 3, pp. 703-720. https://doi.org/10.1108/BPMJ-03-2016-0056

Buys, A. J.; Stander, M. J. (2010), "Linking projects to business strategy through project portfolio management", South African Journal of Industrial Engineering, Vol. 21, No. 1, pp. 59-68. https://doi.org/10.7166/21-1-66

Cândido, C. J. F; Santos, S. P. (2015), "Strategy implementation: what is the failure rate?", Journal of Management
\& Organization, Vol. 21, No. 2, pp. 237-262. http://dx.doi. org/10.1017/jmo.2014.77

Carvalho, M. M.; Lopes, P. V. B. V. L.; Marzagão, D. S. L. (2013), "Project portfolio management: Trends and contributions of literature", Gestão \& Produção, Vol. 20, No. 2, pp. 433454. http://dx.doi.org/10.1590/S0104-530X2013000200013

Chronéer, D.; Backlund, F. (2015), “A holistic view on learning in project-based organizations", Project Management Journal, Vol. 46, No. 3, pp. 61-74. https://doi.org/10.1002/pmj.21503

Fink, A. (2005), Conducting Research Literature Reviews: From the Internet to Paper, Sage, California.

Freitas, C. A. (2016), Gestão estratégica por meio de projetos, programas e portfólio, Brasport, Rio de Janeiro.

Hax, A. C.; Wilde, D. L. (2001), The Delta Project: discovering new sources or profitability in a networked economy, Palgrave, New York.

Kelm, M. S.; Baggio, D. K.; Kelm, M. L. et al. (2014), “A inovação como estratégia competitiva das organizações: um ensaio teórico", Revista de Administração IMED, Vol. 4, No. 3, pp. 274-285. https://doi.org/10.18256/2237-7956/raimed. v4n3p274-285

Kim, C. W; Mauborgne, R. (2005), A estratégia do oceano azul: como criar novos mercados e tornar a concorrência irrelevante (7th ed.), Elsevier, Rio de Janeiro.

Kim, D.-J (2007), "Falls from grace and lessons from failure: Daewoo and Medison", Long Range Planning, Vol. 40, No. 4-5, pp. 446-464. https://doi.org/10.1016/j.Irp.2007.06.003

Longoni, A.; Cagliano, R. (2015), “Environmental and social sustainability priorities: their integration in operations strategies", International Journal of Operations \& Production Management, Vol. 35, No. 2, pp. 216-245. https://doi.org/10.1108/ IJOPM-04-2013-0182

Nalebuff, B.J.; Brandenburger, A.M. (1996), Co-opetição: um conceito revolucionário que combina competição e cooperação; a estratégia da teoria do jogo que está mudando o jogo dos negócios, Rocco, Rio de Janeiro.

Nara, E. O. B.; Kipper, L. M.; Siluk, J. C. M. et al. (2014), "The view of the process management in its different levels: a study case of process maturity", Latin American Applied Research, Vol. 44, No. 2, pp. 111-117. Available from: http://www. laar.uns.edu.ar/indexes/artic_v4402/44_02_111.pdf (access March 2017)

Project Management Institute - PMI (2014), Um guia do conhecimento em gerenciamento de projetos (guia PMBOK) (5th ed), Project Management Institute, Pennsylvania.

Ronda-Pupo, G.; Guerras-Martin, L. A. (2012), “Dynamics of the evolution of strategy concept 1962-2008: a co-world analysis", Strategic Management Journal, Vol. 33, pp. 162188. http://dx.doi.org/10.1002/smj.948 
Scotelano, L. S.; Conceição, R. D. P., Leonídio, U. D. C. et al. (2017), "Project management maturity model: the case in an automotive industry in Brazil", Brazilian Journal of Operations \& Production Management, Vol. 14, No. 4, pp. 500-507. https://doi.org/10.14488/BJOPM.2017.v14.n4.a6

Siegel, S.; Castellan, N. J. (2006), Estatística não-paramétrica para ciências do comportamento (2nd ed), (S.I.C. Carmona. Trans), Artmed, Porto Alegre.

Silva, S. B.; Villan, W. J. (2018), “O Papel da Coopetição na Criação de Valor para Micro e Pequenas Empresas - MPEs no Âmbito da Cadeia de Suprimentos em Relações Fornecedor-Fornecedor", Revista de Administração, Sociedade e Inovação, Vol. 4, No. 1. https://doi.org/10.20401/rasi.4.1.176

Škrinjar, R.; Trkman, P. (2013), “Increasing process orientation with business process management: critical practices", International Journal of Information Management, Vol. 33, No. 1, pp. 48-60. http://dx.doi.org/10.1016/j.ijinfomgt.2012.05.011

Sterling, J. (2003), "Translating strategy into effective implementation: dispelling the myths and highlighting what works", Strategy \& Leadership, Vol. 31, No. 3, pp. 27-34. https://doi.org/10.1108/10878570310472737

Suarez, E.; Calvo-Mora, A.; Roldán, J. L. (2016), “The role of strategic planning in excellence management systems", Euro- pean Journal of Operational Research, Vol. 248, pp. 532-542. http://dx.doi.org/10.1016/j.ejor.2015.07.008.

Sull, D. N. (2007), "Closing the Gap Between Strategy and Execution", MIT Sloan Management Review, Vol. 48, No. 4. Available from: https://www.researchgate.net/publication/39334469_Closing_the_Gap_Between_Strategy_and_ Execution (access March 2017)

Sweeney, D. J.; Willians, T. A.; Anderson, D. R. (2015), Estatística aplicada à Administração e Economia (3rd ed), Cengange Learning, São Paulo.

Treinta, F., Filho, J., Chagas, D. et al. (2014), "The integration between corporate and operational strategies: an analysis of scientific publications using a bibliometric method", Brazilian Journal of Operations \& Production Management, Vol. 11, No. 1, pp. 7-25. Retrieved from https://bjopm.emnuvens.com.br/ bjopm/article/view/V11N1A1

Xavier, L. C.; Barbosa, R. F.; Sousa, J. E. (2015), “A estratégia do oceano azul: um estudo de caso numa empresa de serviços na cidade de Campina Grande - PB", Revista Gestão, Inovação e Tecnologias, Vol. 5, No. 3, pp. 2348- 2365. https://doi. org/10.7198/geintec.v5i3.423

Zollo, M.; Minoja, M.; Coda, V. (2017), “Toward an integrated theory of strategy", Strategic Management Journal, Vol. 39, No. 6, pp. 1753-1778. https://doi.org/10.1002/smj.2712

Received: 07 Apr 2019

Approved: 20 May 2019

DOI: 10.14488/BJOPM.2019.v16.n4.a6

How to cite: Ferreira, S. A.; Vieira Neto, J.; Batista, H. M. C. S. et al. (2019), “Critical success factors on project and process management in competitive strategy implementation", Brazilian Journal of Operations \& Production Management, Vol. 16, No. 4, pp. 605-616, available from: https://bjopm.emnuvens.com.br/bjopm/article/ view/838 (access year month day). 